Yayınlayan: Ankara Üniversitesi KASAUM

Adres: Kadın Sorunları Araştırma ve Uygulama Merkezi, Cebeci 06590 Ankara

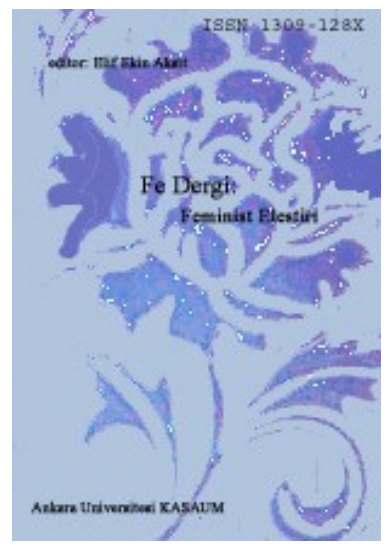

Fe Dergi: Feminist Eleştiri 4, Sayı 1

Erişim bilgileri, makale sunumu ve ayrıntılar için:

http://cins.ankara.edu.tr/

Hıristiyanlığın İlk Yıllarında Akdeniz Ülkelerini Etkisi

Altına Alan Kadın: Tekla

Nermin Öztürk

Çevrimiçi yayına başlama tarihi: 15 Haziran 2012

Bu makaleyi alıntılamak için: Nermin Öztürk, "Hıristiyanlığın İlk Yıllarında Akdeniz Ülkelerini Etkisi Altına Alan Kadın: Tekla," Fe Dergi 4, sayı 1 (2012), 42-53.

URL: http://cins.ankara.edu.tr/7_4.html

Bu eser akademik faaliyetlerde ve referans verilerek kullanılabilir. Hiçbir şekilde izin alınmaksızın çoğaltılamaz. 


\title{
Hıristiyanlığın İlk Yıllarında Akdeniz Ülkelerini Etkisi Altına Alan Kadın: Tekla
} Nermin Öztürk*

\begin{abstract}
Konya/İkonium'da doğup Silifke/Seleucia'de ölen Tekla erken Hıristiyanlık döneminin en önemli kadın şahsiyetlerinden birisidir. O, Hiristiyanlıkla Pavlus'un Anadolu'ya yaptı̆̆ ilk misyon yolculuğu sırasında Konya'da tanışır ve Pavlus'un ögrencisi olur. Hıristiyan kilisesinin kuruluşunda havarilerin arasında aktif olarak görev yapar. Bu gün bile Kilisedeki kadınların sahip olamadıkları ögretme yetkisi ve vaftiz gibi sakramentleri icra eder. Ayrıca Hiristiyanlı̆̆ın ilk kadın şehidi kabul edilir. Yaşantısılla insanlar öylesine derinden etkiler ki ölümünden sonra özellikle Akdeniz ülkelerindeki Hıristiyanlar arasında bir Tekla kültü oluşmasına sebep olur. Günümüzün Batı dünyasında da o hem kendini kiliseye adamış kadınlar hem de feministler için rol model olmayı sürdürmektedir.
\end{abstract}

\section{Anahtar Sözcükler: Silifke/ Seleucia, Tekla, Hıristiyanlı, Öncü Kadın}

\begin{abstract}
The Woman Who Has Affected the Mediterranean Countries at the Early Years of Christianity: Tekla

Tekla, born in Iconium and died in Seleucia, is one of the important female personalities of the early Christian era. She meets Christianity during Pavlus' first trip on a mission to Iconium and becomes his pupil. She plays an active role in founding of the Chrtistian church among the apostles. She performs sacraments such as the authority to teach and to baptise where women do not have access even today. In addition, she is considered to be the first female martyr of Christianity. Having influenced the people deeply with her life, a Tekla Cult comes into existence particularly among the Christians in the Meditterranean countries following her death. As for today's Western world, she still continues to be a role model both for the feminists and the women who dedicated themselves to the church.
\end{abstract}

Keywords: Silifke/Seleucia, Thecla, Christianity, the Pioneer Woman

\section{Giriş}

Semavi dinler olarak adlandırılan Yahudilik, Hıristiyanlık ve İslam dininin kurucularının hayatlarına bakılacak olursa hepsinin yanı başında birer kadın oldukları görülecektir. Yahudiliğin kurucusu Musa'nın hayatında kız kardeşi Meryem'in önemli bir rolü vardır. Firavun'un ölüm emrinden kurtarmak için annesinin içine Musa'yı koyarak nehre bıraktığı sandukayı izleyen ve sanduka Firavun'un kızı tarafından bulununca "size bebek için bir süt anne bulayım mı” diyerek anne ile bebeği tekrar buluşturan kişi odur. İsrailoğullarının Mısır'dan çıkışlarında Harun'la birlikte Musa'ya yardım eden yine odur. İsa'nın yanında tüm kalbiyle ona inanıp önce ayaklarını sonra başını kutsal yağla yağlayan Mecdelli Meryem, Muhammed'in yanında kendisine ilk inanan, maddi manevi her şeyiyle destek olan eşi Hatice vardır.

Hıristiyanlığın bu günkü şekliyle kurucusu kabul edilen Pavlus'un yanında ise havarilerin yanı sıra bir de kadın vardır. Bu kadının adı Tekla'dır . Hayat yolculuğu Konya'da başlayıp Silifke'de son bulan Tekla ardında silinmeyecek izler bırakmıştır. Halen doğduğu kent Konya'da aktif haldeki Aziz Pavlus kilisesinin duvarındaki ikonasıyla hatıratı taze tutulmaya çalışılır; öldüğü yer olan Silifke ise onunla kutsallaşmış ve Hıristiyanlar için hac mekânına dönüştürülmüştür.

Bilindiği üzere Silifke M.Ö. 300 tarihlerinde Büyük İskender'in komutanlarından 1. Seleucus Nicator tarafından kurulmuş ve miladi birinci yüzyıldan itibaren de Hıristiyanlar için önemli bir kent olmuştur. ${ }^{1}$ Dördüncü yüzyıl başlarında Provincia Isauria'nın Metropolitliği olan kent, 359 yılında Ariusçulukla ilgili bir konsile ev sahipliği yapmış ve diğer bazı konsillere de temsilciler göndermiştir. ${ }^{2}$ Fakat tüm bunların yanı sıra kenti Hıristiyanlar açısından kutsal ve önemli kılan asıl neden yukarıda da söz ettiğimiz gibi Azize Tekla'dır. Tekla Pavlus'un Anadolu'ya yaptığı misyon yolculukları sırasında Konya'da (İkonium) Hıristiyanlıkla tanışmış, sonraki yaşantısını bu din uğruna harcamış ve kilise tarafından azize ilan edilmiş bir kadındır. Ölümünün ardından ömrünün bir kısmını geçirdiğine ve orada kaybolduğuna inanılan mağara Hıristiyanlar tarafından hac

\footnotetext{
${ }^{*}$ Yrd. Doç. Dr., Felsefe ve Din Bilimleri, Konya Üniversitesi .
} 
mekânına dönüştürülmüştür. Silifke'de Meryemlik olarak bilinen bu yer, olayın üzerinden iki bin yıldan fazla zaman geçmiş olmasına rağmen Hıristiyanlar için cazibe merkezi olmaya devam etmektedir.

İkinci yüzyıl gibi oldukça erken dönemli yazmalarda adına rastlanan Tekla'nın ünü üçüncü ve dördüncü yüzyıllarda tüm Akdeniz kıyılarını sarmış, Silifke'den Mısır'a, Fransa'dan Filistin'e kadar uzanmıştır. Onun zahitliği, bakireliği ve şehitliği dillerden düşmemiş, hem yazarlar hem sanatçılar tarafindan eserlerine konu edilmiş, özellikle kadınlar arasında ilham kaynağı olmuştur. Adına açılan kilise ve manastırlarla, onu öven edebi eserlerle, kayalara kazınan heykelleri, tuvallere çizilen resimleri, hatta kumaşlara dokunan figürleri ve bulunduğu yerlere yapılan hac ziyaretleriyle bir kült oluşmuştur. ${ }^{3}$

Erken Hıristiyanlık döneminde kadınlar doğan kız çocuklarına onun adını koymuşlar, vaizler kadının iffetliliği söz konusu olduğunda onu anlatmışlardır. Kilise babalarından Milan piskoposu Ambrose (d.337-340, ö.397) genç kızlara, Bakire Meryem'den sonra örnek almaları gereken tek şahsiyetin Tekla olması konusunda 1srar etmiştir. ${ }^{4}$ Methodius 300 yıllarında yazdığı Symposium'unda bakireler arasında Tekla'yı başköşeye oturtmuştur. Nazianzus'lu Gregory (329-389) onu nişanlısının zulmünden ve evlilikten kaçan biri olarak ifade etmiştir. Nyssa'lı Gregory (335-394) ise ondan havari Pavlus'un bakire müridi olarak bahsetmiştir. ${ }^{5}$

Özellikle dördüncü yüzyılda kendilerini Hıristiyanlığa adayan bazı kadınların da Tekla ile özdeşleştirildiği görülmüştür. Mesela Kilise Babalarından Kapadokyalı aziz Basil (330-379) ve Nyssa'lı Gregory'nin adından övgüyle bahsettikleri rahibe Macrina'nın (324-379) annesi, gördügü bir vizyonun etkisiyle, kızından "yeni Tekla" olarak söz etmiştir. Yine Kilise Babalarından Aziz Jerome (347-420) dördüncü yüzyılda Kudüs Zeytin Dağı'nda bir manastır inşa ettiren Romalı asilzade Yaşlı Melania’yı (325-410) "Yeni Tekla" diye isimlendirmiştir. ${ }^{6}$

Günümüzde her ne kadar bazı çevreler tarafından Tekla'nın tarihselliği sorgulansa ${ }^{7}$ ve Katolik kilisesi tarafından Tekla'nın adı azizeler listesinden çıkarılsa $\mathrm{da}^{8}{ }^{8} \mathrm{bu}$ durum onun hem Doğu hem Batı kiliseleri tarafından anılmasını engelleyememiştir. Yunan kilisesi onu kadınlar arasında şehitliğin öncüsü olarak görmüş, havarilere eşit saymıştır. Doğu Ortodoks Kiliselerinde 24 Eylül, Katolik kiliselerde ise 23 Eylül günü Tekla Bayramı olarak kutlanmaktadır. ${ }^{9}$

Avrupa ve Amerika'da pek çok kiliseye onun adı verilmiştir. O, İspanya'da Tarragona şehrinin baş azizesidir. Çok eski zamanlardan beri Tekla'nın kült merkezi olan ve Tekla festivaline ev sahipliği yapan kentin önemi, ilerleyen yıllarda, Tekla'nın kolunu muhafaza etmesi sebebiyle daha da artmıştır. Rivayetlere göre bu kol 1320'de Antioch'dan (Antakya) Ermeni Kral Oscinus tarafından Aragon* Kralı II. James'e gönderilmiştir. ${ }^{10}$

Tekla kültünün yaygın olarak görüldüğü yerlerden biri de Mısır'dır. Onun hikâyesi üçüncü yüzyılın ilk yarısından itibaren özellikle İskenderiye'li teolog Origen (184/5-253/4) sayesinde İskenderiye kentinden başlayarak tüm Mısır'a yayılmıştır. Dördüncü yüzyıl ortalarında İskenderiye piskoposu Athanasius (d. 296-298, ö. 373) Tekla'nın hikâyesine özel bir ilgi göstermiş ve Silifke’ye bir hac ziyareti yapmıştır. O, bakirelikle ilgili eseri Virginity'de Tekla'yı kadın dindarlığı için tek model olarak göstermiştir. ${ }^{11}$

Günümüzde Tekla'nın sahiplenildiği ve mezarının olduğu iddia edilen iki önemli ülkeden biri Suriye diğeri İtalya'dır. Tekla kültünün tüm canlılığıyla yaşatıldığı Suriye Maalula'da, Tekla'nın kaldığı iddia edilen mağaranın yanına onun adıyla bir manastır inşa edilmiştir. Hz. İsa'nın konuştuğu dil olan Aramicenin kullanıldığ yoksullara bakarak Tekla geleneğini sürdürmektedirler. ${ }^{12}$

Roma'da da Pavlus'un (5-67) mezarına yakın mesafede Tekla'nın mezarı olduğu iddia edilen bir yer vardır. ${ }^{13} \mathrm{Bu}$ iddia muhtemelen Tekla'nın Silifke'de son bulan hayat hikâyesine bazı yazmalarda eklenen bölüm nedeniyledir. Bu bölümlerde anlatılanlara göre Tekla kendisine kötülük etmek isteyen gençlerden korunmak için mağaradaki bir kaya yarığına girmiş ve buradan Roma’ya gitmiştir. Orada Pavlus'u uyurken bulmuş, çok kısa bir süre sonra kendisi de uykuya dalmış ve Pavlus'a yakın bir yere gömülmüştür. ${ }^{14}$

Tekla'nın hikâyesinin ana kaynağı olan Pavlus ve Teklan'ın İşleri adlı yazmaya göre onun hayatındaki son durak Silifke'dir. Silifke'de Tekla'nın mezarı olduğuna inanılan mağara Silifke Taşucu yolu üzerinde Meryemlik adıyla bilinen yerdedir. Bu mağaranın içinde bir kilise, muhtemelen din adamlarına ait bazı mezarlar ve Tekla'nın kaybolup gittiğine inanılan bir yarık vardır. Mağaranın üst tarafında bugün yalnızca apsisi ayakta kalabilen, 460-470 yıllarında yapıldığı anlaşılan bir kilise kalıntısı mevcuttur. Bu kilisenin apsisi aşağıdaki mağarada Tekla'nın kaybolduğuna inanılan yarığın üstüne denk gelir. Buranın yaklaşık yüz elli metre kuzeyinde Isauria'lı imparator Zenon (474-475 ve 476-491) tarafından, muhtemelen bir zafer sonrası şükran ifadesi olarak yaptırılan başka bir kilise kalıntısı ile otuz metre kadar kuzeydoğusunda büyük bir sarnıç bulunur. ${ }^{15}$ Kalıntıların tarihlerinden de anlaşılacağı üzere mağara Roma imparatorluğunun dördüncü yüzyılda 
Hıristiyanlığı tanımasına kadar inananlar tarafından gizli bir mabet olarak kullanılmış, bu tarihten itibaren de kiliseye dönüştürülmüş ve yanına başka kiliseler inşa edilmiştir.

Biz bu çalışmada bir kadın olarak Hz. Meryem'den sonra Hıristiyan çevrelerde böylesine derin izler bırakmış, özellikle Akdeniz kıyılarındaki ülkelere damgasını vurmuş olan Tekla’nın böylesi popüler bir şahsiyet olmasına sebep olan özellikleri üzerinde durmak istedik. Yalnız konuya geçmeden önce Tekla'nın hayatından bahsetmek istiyoruz.

\section{Tekla'nın Hayatı}

Yukarıda da söz ettiğimiz gibi Tekla hakkındaki bilgiler M. ikinci yüzyıla ait olan "Pavlus ve Tekla'nın İşleri” adlı yazmaya dayanır. ${ }^{16}$ Kilise tarafindan apokrif* kabul edilen bu yazmadaki bilgilere göre Pavlus ile Tekla ilk kez Konya'da (İkonium) karşılaşırlar. Pavlus yanında Barnabas olduğu halde Hıristiyanlığı yaymak üzere Konya'ya geldiğinde ${ }^{17}$ Tekla şehrin önemli ailelerinden birine mensup nişanlı bir genç kızdır. Pavlus burada Onesiphorus'un evinde bâkirelikle ilgili bir vaaz verir. Vaazı, bitişikteki evlerinin penceresinden, üç gün üç gece yerinden kalkmaksızın dinleyen Tekla öylesine etkilenir ki evlenmekten vazgeçer ve kendini Hıristiyanlığa adar. Kızının Hıristiyan olmasını istemeyen anne ile terk edilen nişanlı ne kadar dil dökseler de onu kararından vazgeçiremezler. Duruma iyilikle çözüm bulamayacaklarına kanaat getiren anne ile nişanlı bir komplo hazırlayarak Pavlus'u zindana attırır ve Tekla'nın onu görmesine engel olmaya çalışırlar. Fakat Tekla gardiyanlara değerli eşyalar ve mücevherlerinden vererek Pavlus'un hücresine girmeyi başarır ve onun öğretilerini dinlemeyi zindanda da sürdürür. Kızlarının zindanda Pavlus'un yanında olduğunu öğrenen aile onları oradan çıkartır, yeniden sorgulanırlar. Sorgulamanın sonunda Pavlus'un kırbaçlanarak şehir dışı edilmesine, Tekla'nın da başka kadınlara örnek olmasın diye annesinin de arzusuyla yakılarak öldürülmesine karar verilir. Soyularak ateşe atılan Tekla mucizevî şekilde başlayan yağmur ve dolu sayesinde yanmaktan kurtulur. ${ }^{18}$

$\mathrm{Bu}$ olaydan sonra Pavlus ile Tekla yeniden buluşur ve Pisidya Antakyasına doğru yola çıkarlar. Sıkıntılar burada da Tekla'nın peşini bırakmaz. Şehrin ileri gelenlerinden Alexander isimli birisi Tekla'dan çok hoşlanıp birlikte olmak ister. Sokak ortasında Tekla'ya sarkıntılık edince Tekla kendini savunmak isterken adamın elbisesi yırtılır. Rezil olan adam intikam almak için Tekla'yı sürükleyerek valiye götürür ve şikâyetçi olur. Bu kez Tekla'nın vahşi hayvanlara yem olarak atılmasına karar verilir. Fakat burada da mucizevî olaylar birbirini izler. Tekla’yı parçalayarak yemesi beklenen aslan onun ayaklarını yalar. Üstelik Tekla’ya saldırmak isteyen bir ayıyı öldürür, diğer hayvanları da kovar. Sonra onu vahşi boğalara bağlarlar ama yine başarısız olurlar. Son olarak Tekla'yı insan eti yiyen balıklarla dolu bir gölete atarlar. Burada da balıkların ona saldırması şöyle dursun, Tekla sulardan vaftiz olarak çıkar. İmparatorun yakınlarından olan Tryphaena adlı nüfuzlu bir kadın bu mucizelere şahit olarak bayılır. Tryphaena'nın başına bir şey gelmesinden ve olayları imparatorun öğrenip cezalandırmasından korkulduğu için Tekla serbest bırakılır. Bir süre Tryphaena'nın himayesinde kalan Tekla, Pavlus'un Demre'de (Myra) olduğunu öğrenip erkek kılığına girerek yollara düşer. Pavlus'la buluşunca olup biteni anlatır; Pavlus da ona Hıristiyanlığı yayma görev ve yetkisini verir. Tekla memleketi Konya'ya geri döner, nişanlısı ölmüştür. Annesini İsa'nın dinine davet eden Tekla bir süre daha burada kalıp, buradan öldüğü yer olan Silifke'ye (Seleucia) gider. ${ }^{19}$

Bazı yazmalardaki ilave bölümlerde Tekla'nın Silifke'de Kalamon dağında yabani otlar yiyip su içerek hayatını sürdürdüğünden bahsedilir. Rivayetlere göre o bir taraftan inandıklarını anlatırken diğer taraftan da hasta insanları iyileştirmektedir. Civardaki putperestler onun tanrıça Artemis'in elçisi olduğuna hükmederler. Tekla'nın gösterdiği olağan üstü halleri kıskananlar ile hastaları ellerinden alınan bazı hekimler onun gücünü bakireliğinden aldığına inanarak bunu yok etmek üzere bazı serseri ve sarhoşları üzerine gönderirler. O sıralarda doksan yaş civarında olduğu söylenen Tekla mağaradaki bir kaya yarığına girerek kaybolur, onu bir daha gören olmaz. ${ }^{20}$

\section{Tekla'nın Bakireliği}

Hayat hikâyesinde anlatıldığı gibi Tekla'nın Hıristiyanlık hakkında duyduğu ilk söylemler bakirelikle alakalıdır. O, Pavlus’un konu ile ilgili sözlerinin öylesine etkisi altında kalır ki evlenmek üzere olduğu nişanlısını terk eder. Dolayısıyla onun Hıristiyanlıkla ilgili olarak yaptığı ilk icraatların başında bakireliği tercih edişi gelir.

Aslında evlenmemek veya cinsel ilişkilerden uzak durmak Hıristiyanlıktan önceki ve sonraki bazı dini organizasyonlarda da görülen ve spritüel yaşamı olumsuz etkilediğine inanılan bir realitedir. Antik Roma'da Vesta rahibeleri, Uzak Doğu'da Hindu çilecileri, Budist keşişleri ve geneli kapsamasa da bazı Müslüman mutasavvıfların durumu örnek olarak gösterilebilir. Hıristiyanlığın ilk yıllarına bakıldığında da görülecektir ki, 
gerek Kilise Baba'larından gerekse halktan daha sağlıklı bir ruhani yaşam için evlenmemeyi tercih edenler çıkmıştır. Katolik kilisesinde rahiplerin evlenmemeleriyle ilgili kurallar ise Hıristiyanlığın ilk yıllarında görülmeyip, dinin organize olmasıyla sonradan konulmuştur.

Tekla'nın yaşadığı dönemdeki bekârlık kavramına hem Roma düşüncesi hem de Yahudi dini açısından bakmak sanırız faydalı olacaktır. Çünkü Tekla'nın yaşadığı topraklarda siyasi otorite Roma imparatorluğudur ve bilindiği üzere Hıristiyanlık Roma hâkimiyetindeki topraklarda doğmuştur. O sıralar Romanın dini putperestliktir. Yahudiler ise kendi aralarında kendi şeriatlarına, dış işlerinde Roma'ya bağlı olarak yaşamaktadırlar. O dönemde devlet tarafından Roma vatandaşlarının çoğalması istendiği için normal durumlarda bekâr kalmak cezalandırılırdı. Hatta dini görevleri dolayısıyla bakirelik zorunluluğu olan Vesta Rahibelerinin bile otuz yıllık görev sürelerinin dolmasıyla evlenmelerine izin verilirdi. Legal yollarla üremeye yapılan bu vurgunun arkasında belki de klasik kültürel inançta cinsel zevklerin potansiyel olarak tehlikeli ve anti sosyal olduğuna ilişkin görüş vardı. Cinsel zevkler sembolik olarak ateşle ilişkilendiriliyor, orgazm ise ufak çaplı bir sara nöbeti olarak kabul ediliyordu. Dahası, cinsel birleşmenin insanın hayati gücünü tedricen kaybettireceğine inanılıyordu. Seksin sadece çocuk yapmak için olduğu savunuluyor, zevk almak için bunu yapanlar hoş karşılanmıyor ve bu işin tehlikeleri vurgulanıyordu. İşte hem cezai müeyyideler hem de halk arasındaki bu inançlardan olsa gerek, Roma vatandaşları arasında bekârlık yaygın bir şey değildi. ${ }^{21}$ Roma felsefi düşüncesinde ise bir kavram olarak bekârlık, kendini kontrol etme, arzulardan geri durmak veya yapmamak şeklinde tanımlanırdı. Seksüel davranışlar söz konusu olduğunda da bu kendine hâkim olma durumu, seksüel aktivitelerin bir erkeğin hayat enerjisini yok edeceği veya zarar vereceği yönündeki fikirle uygunluk içindeydi. Dolayısıyla Hıristiyanlıktaki bekârlık kavramı ile Roma felsefesinde insanın kendini seksüel arzulardan geri tutması olarak tanımlanan bekârlık arasında ortak bir payda vardı. ${ }^{22}$

Yahudilik açısından bakıldığında ise durum biraz karışıktı. Özellikle antik Yahudilikte bekârlığa karşı güçlü bir direniş vardı. Evlilik hem normal bir insani davranış hem de ilahi bir emir olarak kabul edilmişti. Rabbinik Yahudilikte evlenmemiş bir erkek tam bir insan değildi. Üstelik cinsel perhiz de bir erdem değildi, çünkü bu yaradılışın amacıyla çatışırdı. ${ }^{23}$ Başta İbrahim olmak üzere Musa, Davut, Süleyman, Zekeriya ve daha pek çok peygamber evli ve çoluk çocuk sahibiydiler. Dindar Yahudiler için bekârlığın veya iffetin anlamı evlilikte yasaklanmış ilişkilerden kaçınmaktı. ${ }^{24}$ Fakat Yahudilikte de kutsallık fikriyle seksüel ilişkilerin bağlantılı olduğu durumlar vardı: kadınların menstrüel dönemleri ve naziritelerin (adanmışlar) durumlarında olduğu gibi. Yalnız bunlar bekârlık anlamında değil, geçici durumlardı. ${ }^{25}$ İstisnai olarak Yahudilik tarihinde bekarlığın küçük bir rol oynadığı iki marjinal hareket vardı: Esseniler ve Therapeutride'ler. ${ }^{26}$

İsa'nın annesi Meryem'in durumu naziritelerin durumuna uygunluk gösterir. Kendisi doğumundan önce Kutsal Tapınak için adanmış bir nazirdir. Çünkü zaten Tevrat'a göre doğan ilk erkek çocukların Rabbe adanması gerekmektedir. ${ }^{27}$ İlerlemiş yaşlarında ana-baba olma şansını yakalayan Meryem'in ailesi, doğan ilk çocukları kız olmasına rağmen, kural dışı olarak onu çocukken tapınağa vermişlerdir. Meryem de oğlu İsa'yı doğan ilk çocuk olması sebebiyle Yahudi şeriatına göre tapınağa vermiştir. ${ }^{28}$ Fakat daha önce de belirttiğimiz gibi bu durumların sürekli olması gerekmez. Nitekim tapınakta da ömür boyu kalmamışlardır. Buna rağmen Hıristiyanlığın ilerleyen yıllarındaki tablo, insanların İsa'nın bakire bir anneden doğuşu ve bekâr kalışı ile havarilerden bazılarının ${ }^{29}$ cinsel riyazeti tercih edişlerinden etkilendiklerini gösterir. Özellikle erken dönem Hıristiyanlıkta ömür boyu bekârlık, kurtuluş için en etkili yol olarak kabul edilmiştir. ${ }^{30}$

İsa'nın seksüel ahlakla ilgili görüşleri Yeni Ahit’te yer almıştır. ${ }^{31}$ Tanrının krallığına girebilmek için bekârlığa vurgu yapan İsa evliliği yasaklamamıştır. ${ }^{32}$ Onun boşanmayı yasaklayan sözleri ise öğrencileri tarafından bu durumda evlenmemenin daha uygun olacağı şeklinde yorumlanmış; İsa da buna herkesin güç yetiremeyeceğini söylemiştir. ${ }^{33}$

Hıristiyanlığın mimarı ve en önemli yorumcularından olan Pavlus’un cinsellik, evlilik, boşanma, aile, bekârlık gibi konular hakkındaki kanonik görüşlerini Korintlilere yazdığı birinci mektup ${ }^{34}$ ile Efeslilere yazdı̆̆ mektupta ${ }^{35}$ bulmak mümkündür. ${ }^{36}$ Pavlus, Korintlilere tanrı vergisi cinsel arzularını baskılamamayı tavsiye etmiştir; onlara arzularına hâkim olamayacaklarsa evlenmelerini önermiştir. Tekla ile hikâyesinin anlatıldığı Apokrif İncilde ise "kutluluğu" tanımlarken inançla bakireliği aynı kefeye koymuş, ${ }^{37}$ bakireliği tanrıyla dolu kutsal yaşamla direkt olarak ilişkilendirmiş ve Göksel Krallığın ön şartı olarak kabul etmiştir. ${ }^{38}$

Tekla'nın bakireliği tercih edişinde Pavlus'un sözlerinin yanı sıra içinde bulunduğu sosyokültürel çevredeki yaygın inançlar rol oynamış olabilir. Zira bakirelik hem Hıristiyanlar hem putperest Romalılar için yüce bir idealdir ve böyle bir yaşamı tercih edenlerin sipirtüel bilgeliğe ve şifa gücüne sahip olacakları inanc1 ${ }^{39}$ iki taraf arasında da yaygındır. Zaten bu yüzden kendisine hem paganlar hem Hıristiyanlar saygı duymuşlar ve 
yüceltmişlerdir. Silifke'de paganlar onu tanrıça Artemis'in elçisi olarak görmüşler, kilise babaları ona iltifat etmişler, övmüşler ve bakireliği ile dindarlı̆̆ını bir saymışlardır.

\section{Tekla'nın Dindarlı̆̆ı}

Pavlus ve Teklanın İşleri bize Tekla'nın diğer özellikleri hakkında da ipuçları verir. Her şeyden önce o, Pavlus'la karşılaşıı̆ında genç ve güzel bir kızdır; nitekim Pisidya Antakyasında şehrin ortasında bir erkeğin dikkatini çekmiş ve onun uygunsuz davranışlarına maruz kalmış, ama iffetini muhafaza etmiştir. ${ }^{40}$ Bundan başka o soylu ve varlıklı bir aileye mensuptur; hapishaneye Pavlus'un yanına girebilmek için mücevherlerini ve değerli bazı eşyalarını gardiyanlara vermiş̧tir. Bu onun inancı uğruna maddi varlığından geçecek kadar idealist ve samimi olduğunu gösterir. "Gönüllü yoksulluk" olarak tanımlanabilecek bu durum ${ }^{41}$ İsa'nın öğretileri arasında şöyle yer alır: Adamın biri İsa' ya gelerek sonsuz yaşama kavuşabilmesi için ne yapması gerektiğini sorar. İsa ona adam öldürmeme, zina etmeme, çalmama, yalan yere tanıklık etmeme, ana-babaya saygı ve komşu hakkını gözetme konularına dikkat etmesini ister. Adam bunları zaten yaptığını ama daha başka neler yapması gerektiğini sorar. İsa da ona nesi varsa satıp yoksullara vermesini, böylece göklerde bir hazineye kavuşacağını söyler; çünkü zenginlerin göklerin egemenliğine girmesi zordur. ${ }^{42}$

Tekla'nın gençliğini ve güzelliğini dünyevi yaşam için bir avantaja dönüştürmemesi, üstelik nişanlısını ve ailesini terk etmesi İsa'nın havarilerine öğütlediği yaşam şekliyle de uygunluk içerisindedir. İsa, kendisi adına evlerini, kardeşlerini, anne ya da babalarını, çocuklarını veya topraklarını bırakan herkesin bunların yüz katını elde edeceğini ve sonsuz yaşamın mirasçısı olacaklarını söylemiştir. ${ }^{43}$

Tekla'nın bu şekilde riyazetle dolu bir yaşamı tercih etmesinin yanı sıra başından geçen bir takım olaylardaki duruşu da sonraki yıllarda kadın dindarlığı için örnek gösterilmiş davranışlardır. Onun, kendisine sahip olmak isteyenler karşısındaki tutumu ile çırılçıplak soyulup vahşi hayvanlara atılmak üzere arenaya konduğundaki tavırları kilisenin özellikle kadın ve cinsellik konularındaki meselelere çözüm üretmesinde rehberlik etmiştir. Çünkü o zamanlar, kadınların erkeklerin baştan çıkarılmasının baş müsebbibi görüldüğü ve günaha girilmemesi için kadınlardan uzak durulmasının savunulduğu bir dönemdir. Bu yüzden giderek artan şekilde kadınlar kapalı kapılar arkasına itilmektedir. Söylediklerinde abartı var mıdır bilemeyiz ama mesela; Tertullian üçüncü yüzyıl civarında hasta ziyareti ve ibadet dışında kadınların neredeyse halk içinde görülmediklerinden söz eder. ${ }^{44}$

Tekla'nın gönüllü seçimi onun giyimine ve yaşam şekline de yansımıştır. Onu iki tür kıyafet içinde görürüz ki bunlardan biri erkek kıyafeti, diğeri çileci bir yaşamı tercih eden insanların kullandığ kıyafettir. O zamanlar elbiseler kişinin sosyal statüsünü gösteren birer kimlik kartı gibidirler ve "elbise değiştirmek" terimi "çileci bir yaşamı benimsemek" veya "yeni bir topluluğa girmek" gibi metaforik anlamlar taşımaktadır. ${ }^{45}$ Dindar yaşamı tercih eden kadınların hem statülerini belli eden, hem de karşı cinsin ilgisini çeken elbiselerden uzak durmaları gerekmektedir. Elbiselerinin tıpkı fakirlerinki gibi siyah veya boyanmamış kumaştan olması, bedeni ve saçları tümüyle gizlemesi, başın örtülü olması şartı vardır. Çilecilerin yolunu seçen Tekla da, manastırlardaki bakirelerin geleneksel giysileri gibi ve zamanın zihniyetine uygun olarak karşı cinsin arzularını provoke etmeyecek ş̧ekilde, eski püskü siyah bir harmaniyle örtünmüştür. Kendisini betimleyen değişik zamanlardan günümüze kadar gelmiş sanat eserlerinde o, çıplak olarak görüntülendiği yakılma ve hayvanlara yem edilme sahneleri dışında, hep uzun elbisesi ve başörtüsüyle dikkat çeker. ${ }^{46}$ Aslında bakirelerin başörtüsü kullanması o dönemde Roma'daki evlilik törenlerinde gelinin uyması gereken bir adettir ve bu adet Hiristiyanlıkta İsa ile evliliği simgeleyen bir sembole dönüşmüştür. Daha sonraki yıllarda ise Kilise tarafindan rahibelerin siyah örtü ve siyah başörtüsü kullanmaları zorunlu hale getirilmiștir. ${ }^{47}$

Tekla’nın saçlarını kesip erkek elbisesi giyerek fiziksel görünümünde yaptığı diğer değişiklikler de seçtiği yaşam tarzıyla yakından ilgilidir. Bu durum o tarihlerde olağan yaşama arkalarını dönüp riyazet yolunu tercih eden kadınların yaptı̆̆ bir iştir. Çünkü erkek görünümünde olma onlara bazı pratik faydalar sağlar; mesela, cinsiyetleri yüzünden sıklıkla kısıtlanan bağımsız hareket edebilme imkânları veya seyahatler sırasında yaşanabilecek bazı olumsuzluklar, engeller ortadan kalkar ve belli ölçüde korunma avantajını yakalarlar. Zaten Tekla saçlarını keserek Pavlus her nereye giderse kendisini takip edeceğini söylediğinde, Pavlus'un cevabı onun kadın oluşuyla ilgili endişelerini yansıtır mahiyettedir. Pavlus ona zamanın çok kötü ve kendisinin çok güzel olduğunu, başına öncekinden daha kötü olaylar gelebileceğini ve kendisini koruyamayabileceğini hatırlatır. $\mathrm{Bu}$ olay Pavlus'un Pisidya Antakya'sına gitmek üzere Konya'dan ayrılacağı sırada yaşanır. Tekla'nın erkek elbiseleri giymesi ise Yalvaç'ta (Antakya) pek çok işkenceye maruz kalıp, hepsinden kurtularak kendisini vaftiz etmesi sonrasında, Demre'ye (Myra) Pavlus'u aramaya gidişi esnasındadır. Dolayısıyla onun erkeksi 
görüntüsünün yolculukları ile alakalı ve aslında güzelliğini gizlemek için bir strateji olduğu açıktır. Zaten metinde yolculukları dışında böyle bir şeyden söz edilmez. Rivayetlere göre erken monastik dönemlerde çöllerde yaşayan rahibelerden korunma amaçlı bu tür kıyafetleri tercih edenler olmuştur. Ortaçağ başlarında da azizelik makamına yükselmiş bazı bakirelerin ya dünyevi evlilik veya cinsel tacize karşı bir savunma stratejisi olarak yahut da “İsa'nın Gelini” anlamında yeni bir statünün sembolü olarak saçlarını kestirdikleri görülür. ${ }^{48}$

Tekla’nın kadın dindarlığı için örnek gösterilen diğer bir davranışı dünyevi işlerle ilgili suskunluğudur. Her ne kadar Pavlus tarafından kendisine verilen din yayma görevi konuşmayı gerektiriyor olsa da, o daha ziyade sözleriyle değil yaptığı işlerle adından söz ettiren bir eylem kadını görünümündedir. Pavlus ve Teklanın Işslerine göre onun en uzun konuşması Pisidya Antakyası valisinin kim olduğuna ve gücünün nerden geldiğine ilişkin soruya verdiği cevaptır. ${ }^{49}$

Zühdle dolu bir yaşamı seçen insanların uyması gereken diğer bir kural beslenmeyle ilgili olanlardır. Tekla'nın yaşadığı dönemde ise kendini tanrıya adamışlar için henüz Kilisenin yasal beslenme kuralları ortaya çıkmamıştır. ${ }^{50}$ Fakat genel olarak az yemek ve az içmek ile belli besinlerden kaçınmak bu yaşamın en bilinen özelliklerindendir. Nitekim İsa da şeytan tarafından denendiği kırk gün boyunca çölde hiçbir şey yememiştir. ${ }^{51}$ Pavlus açlığı övmüş ${ }^{52}$ ve inancı uğruna günlerce aç, susuz kaldığını ifade etmiştir. ${ }^{53}$ Az yemenin insanın cinsel arzularını bastırmada etkili olduğu inancı, riyazet yolunu seçen pek çok erkeğin yanı sıra kadınlar için de nefisleriyle baş etmenin standart tekniği haline gelmiştir. ${ }^{54}$ Fakat Monastik literatürde yeme içmeden (özellikle katı gıdalardan) sakınmak oruç tutmanın en iyi veya tek şekli olarak kabul edilmez, tam aksine en ehven halidir. Tüm günahlardan kaçınmak, dünyaya ve onun zevklerine uzak durmak, Pavlus ve Tekla'nın İşleri'nde de ifade edildiği gibi "dünyayı inkâr etmek" orucun yüksek formudur. ${ }^{55}$ Dünyayı inkâr etmek, yani dünyadan ve dünyanın lezzetlerinden, zevklerinden kaçınmak insanı yalnızlaştırır ki bu Tekla'nın yaşam tarzı olmuştur. $\mathrm{O}$ ailesini, şehrin en iyi ve en zengin ailelerinden birinin oğlu olan nişanlısını ve memleketini terk ederek bir mağarada kendi başına yaşamıştır. ${ }^{56} \mathrm{Bu}$ anlamda o orucun en makbul olanını tutmuş, neredeyse tüm hayatını oruçla geçirmiştir denilebilir.

\section{Tekla'nın Kerametleri}

Genellikle peygamberler veya dini liderlerle, nadiren de vasat kişilerle ilişkilendirilen mucize, keramet gibi olağanüstü güç gösterimlerinin örneklerine Hıristiyanlıkta sıklıkla rastlanır. Erken dönem kilisenin önemli şahsiyetlerinden biri olan Tekla ile ilgili olarak da bazı sıra dışı olaylar rivayet edilir. Yüzyıllardır ağızdan ağza nakledilen bu rivayetleri yazıldığı iki önemli eser vardır: Bunların ilki Pavlus ve Tekla'nın İşleri'dir; diğeri 470 yıllarında tamamlandığı düşünülen, diğer eserin yaklaşık on katı büyüklükte, Yunanca yazılmış Tekla'nın Hayatı ve Mucizeleri'dir. Ortaçağda bu el yazması kitabı kopyalayanlar eseri beşinci yüzyılda Silifke Piskoposluğu yapmış olan Basil'e atfetmişlerdir. Fakat eserin modern editörü olan Gilbert Dagron eserde geçen bazı olaylara dayanarak bu atıfları reddetmiştir. ${ }^{57} \mathrm{Bu}$ ikinci eser Tekla'nın orijinal hikâyesinin biraz daha genişletilip, aradan geçen üç yüz yıl zarfinda anlatılanların da eklenmesiyle oluşturulmuştur. Bu eserde Tekla'nın kırk altı kerametinden bahsedilir. Bunların hepsini burada sıralamamıza imkân ve gerek yok. Onun daha önce anlattığımız hayat hikâyesi hatırlanacağı gibi zaten büyük ölçüde mucizelerden oluşur. Onları burada tekrarlamayacağız. Yalnız kerametleriyle ilgili en dikkat çekici husus daha inancını ikrar edişiyle birlikte olağanüstü hallerin başlaması, bir sır olan ölümünün de mucizevî bir halle ilişkilendirilmesi ve bu sıra dışı hallerin ölümünden sonra da devam etmesidir.

Tekla’ya atfedilen kerametlerin çoğu sağlıkla ilgilidir. Hikâyelerden anlaşıldığına göre o ölümünden/kayboluşundan sonra bile asırlarca şifa dağıtmıştır. Bu ya rüya yoluyla, ya da mağarasına yapılan ziyaretler ve dualar yoluyla gerçekleşmiştir. Bunlardan birkaç örnek verebiliriz: Dexianos adında dindar bir adam (muhtemelen bir piskopos) gece karanlığında tuvalete giderken çok zalim ve güçlü bir şeytanın saldırısına uğrar, boynu eklem yerinden kayar ve servikal vertebralar yerinden çıkarlar; adamın başı titremeye başlar. Herkesin acıyarak baktığı bu adam rüyasında Tekla'yı görür. Tekla ona umudunu yitirmemesini, gönlünü rahat tutmasını söyler ve iyileşmek için nasıl bir ilaç kullanması gerektiğini anlatır, ona boynuna sürmesi için bir yağ önerir. Dexianos uyanınca bunları yapar ve iyileşir.147 Yine Dexianos'la ilgili olarak anlatılan başka bir hikâyede onun serkeş bir atın üzerinden düşmesi sonucu bacağını kırdığı ve Tekla'nın sayesinde sağlığına yeniden kavuştuğu anlatılır, fakat önceki olayda olduğu gibi tedavinin teferruatından bahsedilmez. ${ }^{58}$

Tekla'nın mucizeleri hakkındaki rivayetlerden anlaşıldığına göre o sadece Hıristiyanlar için değil, her dinden ve milletten insanlar için bir şifacıdır. Mesela, Aba adında pagan bir kadın, Dexianos'un hikâyesinde olduğu gibi, huysuz bir katırın üzerinden düşerek bacağını kırar. Yahudiler de dâhil olmak üzere zamanın en 
ünlü şifacı ve hekimlerine gösterilir, fakat bir türlü iyileşmez. Bunun üzerine Tekla'nın kaybolduğu mağaraya getirilir ve burada iyileşir. ${ }^{59}$ Benzer bir hikâyede de Leontios adlı Hıristiyan bir zanaatkârın başına gelenler anlatılır: Leontios Suriye Antakyası'nda zengin bir adamın evini dekore etmektedir. İskele aniden çöker ve Leontios ağır mermer tabakalarının altında kalır, bacağı çok kötü kırılır ve ezilir, hatta önce öldü zannedilir. Onun iyileşeceğinden ümitler kesildiği sırada Leonites patronuna Tekla'nın yardımını dilemek için Silifke'ye gitmek istediğini söyler. Patron bu arzuyu hafife alarak bıyık altından güler. Leonties Tekla'nın türbesine gider ve üç gün kalır. Söylentiye göre Tekla geceleyin Leonties uyurken gelir ve yaralı bacağının üzerine ayağıyla basar. Leonites acı içinde bağırarak uyanır; iyileşmiştir, eskisinden çok daha sağlıklı ve kuvvetli bir şekilde Antakya'ya döner. Patronu onu görünce hayretler içinde kalır ve bu olayın etkisiyle dinini değiştirir, Hıristiyan olur. $^{60}$

Tekla sadece fiziksel hastalıkları değil, ruhsal hastalıkları da tedavi eder. Bu arada hastalara farklı şekillerde, mesela çocuk kılığında gözüktüğü de olur. Bunun yanı sıra rüyada değil, uyanıkken de görülür. ${ }^{61}$ Türbesinin önünde bulunan kutsal su sadece insanlar değil hasta olan her canlı içi şifa kaynağıdır. ${ }^{62}$

\section{Tekla'nın Şehitliği}

Daha önce de söz ettiğimiz gibi Tekla'nın ölümü ile ilgili bölümler bazı yazmalara eklenen ilave bölümlerde bulunur. Bu bölümlerde anlatılanlara göre Tekla ilerleyen yaşlarına kadar Silifke'de yaşar. Bir tarafta Tanrının sözlerini anlatır, diğer taraftan hastaları mucizevî şekilde tedavi eder. Bu durum Silifke'deki hekimlerin kıskançlığına yol açar. Onlar Tekla’nın güç kaynağının bakireliği olduğunu ve aynı zamanda tanrıça Artemis'ten yardım aldığını düşünürler. Onun bu gizemli gücünü yok etmek için kötü adamlar kiralar ve Tekla'nın üzerine yollarlar. Tekla onları görünce dua eder, mağarada bir kaya yarığı açılır ve Tekla oradan girip kaybolur; yarık kapanır ve geriye sadece elbisesinden bir parça kalır.

Tekla'nın bu şekildeki sonuna veya sır olup kayboluşuna rağmen o Hıristiyanlıkta ilk kadın şehit kabul edilmiştir. Çünkü bilindiği gibi şehitliğin en bilinen tanımı kutsallığına inanılan bir ideal, inanç veya din uğruna canını verebilmektir. $\mathrm{Bu}$ tanım dini ve sosyolojik olarak herkes tarafından kabul edilir. Dolayısıyla Tekla'nın bu anlamda kanını dökerek ulaştığı bir şehitlik mertebesi söz konusu değildir. O her ne kadar böyle bir şeye hazırsa da sonuç itibarıyla kendisi için hazırlanan bütün komplolardan ve tehlikelerden kurtulmuş, huzur içinde ölmüştür. ${ }^{63}$

O halde Tekla niçin ilk kadın şehit kabul edilmiştir? Bunu anlayabilmek için Kilisenin "Şehit" tanımına bakmakta fayda vardır. Bu tanımlamaya göre şehitlik ile şahitlik aynı köktendir. Şehitlik için kullanılan martyr kelimesi eski Yunancada martus, yani kişisel gözlemleriyle bir olay hakkında şahitlik eden kişi demektir. Kelime bu anlamıyla Hıristiyan literatüründe ilk kez İsa'nın yaşantısına ve onun öğretilerine şahit olan havariler için kullanılmıştır. Fakat gerek havariler gerekse ilk Hıristiyanlar, Kilise tarihinde Şehitler veya Kahramanlar Çağı olarak bilinen yıllarda (M. 2-4 yüzyıllar) ${ }^{64}$ bir taraftan Yahudilerin diğer taraftan Romalıların baskısı altında İsa'yı tanımadıklarını/şahadet etmediklerini söylemeye zorlanmışlar, bunu kabul etmeyenlere değişik bedeni ve parasal cezalar uygulanmış, işkence edilmişler, öldürülmüşlerdir. İşte o zaman inançlarının bedelini kanıyla ödeyen bu insanlar için şahit kelimesi, şehit kelimesiyle aynı anlamda kullanılmaya başlanmıştır; ilk inananların zulüm ve işkence ile dökülen kanları aynı zamanda inançlarının şahidi olmuştur. ${ }^{65}$ Tekla'nın çıplak vaziyette ateşe ve ardından yırtıcı hayvanlara atılması, ayrıca diğer başına gelen sıkıntılı ve zor durumlar göz önüne alındığında onun niçin Kilise tarafından şehit ilan edildiği daha iyi anlaşılabilir. Yani burada Tekla'nın şehitliğiyle kastedilen şey, onun olaylar karşısındaki tutum ve davranışlarının, inancının şahidi olmasıdır. Bu açıdan bakıldığında Tekla'nın şehitliği yadsınamaz.

\section{Sonuç}

İki bin yıllık Hıristiyan kilisesi tarihinde kutsallıkları onaylanan binlerce aziz ve azize vardır. Fakat bunların arasında Tekla gibi ta birinci yüzyıldan beri etkisini sürdürebilenler çok azdır; bazıları unutulmuş, bazılarının yalnızca adları veya eserleri kalmıştır. Tekla'nın yaşantısının büyük kısmını geçirdiğine inanılan Silifke'nin bugün hala Hıristiyanlar tarafından hac niyetiyle ziyaret ediliyor olması, Tekla Bayramının Doğu ve Batı kiliselerinde tüm canlılığıyla kutlanıyor olması, adının pek çok kiliseye verilmesi onun Hıristiyanlık açısından önemini kaybetmediğinin göstergeleridir.

Tekla hakkındaki sanat ve edebiyat eserleri ile arkeolojik kalıntılar onun geçmişte nasıl bir ideal, bir sembol olarak alındığını ve ne denli popüler ve zengin bir karakter olduğunu yansıtır; onun hayatı ve felsefesi ile 
ilgilenenlerin nasıl niyetlerine göre onu farklı algıladıklarını ve diğer azizelerden farklı tuttuklarını gösterir. Bunun sebebi ancak onun basit bir azizeden daha öte bir şey olmasiyla izah edilebilir.

Tekla her şeyden önce Kilisenin kurulmasında aktif olarak rol almış birisidir. Kutsal bakirelerin bazı ruhsal güçlere sahip olmaları ve mucizevî olaylarla ilişkilendirilmeleri normaldir ama resmi veya kurumsal bir otorite olmaları sıra dışıdır. O Pavlus'un izni ve onayıyla vaaz etme, öğretme ve vaftiz etme yetkisine sahip olmuş, havarilerle denk tutulmuştur. İki bin yıl önce bir kadın olarak Tekla'nın başardığı bu işler günümüzde aynı hakları elde etmeye çalışan Hıristiyan rahibeler için örnek teşkil etmekte, cesaret vermekte ve Tekla'nın zihinlerde canlı tutulmasına sebep olmaktadır. Onun hikâyesi sadece rahibeler için değil, feministler için de model olmakta ve özgürlüğün anlamını yeniden sorgulatmaktadır. Yani o hâlâ hem dindar kadınlar, hem laik kadınlar arasında rol-model olma özelliğini sürdürmektedir.

Onun hikâyesi aynı zamanda kişinin ideali uğruna izlemesi gereken yolun nasıl zorluklar ve tehlikelerle dolu olduğunun hikâyesidir. Bu yönüyle hem kadınlar hem erkekler tarafından takdir edilen, övülen ve örnek alınan bu husus bize eski Yunan mitolojilerindeki Hero'ları hatırlatır. O tıpkı bir Hero gibi geçmișe ait ne varsa, eski dinini, tüm sosyal ve ekonomik bağlarını, güvenliğini arkasında bırakıp yolculuğa çıkmıştır. Yolculuğunda terk edilmişliği, yalnızlığı, tacizi, şiddeti, ihaneti, ölüm korkusunu deneyimlemiştir. Fakat bütün bunların üstesinden gelmiş, büyük cesaret göstermiş, bu arada hiç tanımadığı insanların yardımına mazhar olmuştur.

Onun öyküsünde farklı dinlerden bazı olağanüstü motifler de bulmak mümkündür. Mesela, ateşe atılıp yanmayışı Yahudilikteki İbrahim ile Nemrut'un hikâyesini hatırlatır. Aslanlarla dost oluşunu betimleyen sanat eserleri ana tanrıça Kibele'yi aslanlar arasında gösteren heykellerle uygunluk içindedir. O, hastaları iyileştirdiğinde paganlar tarafından tanrıça Artemis ile ilişkilendirilmiş, her olumsuzluğa karşı korunan bakireliği ve masumiyeti dolayısıyla da Hıristiyanlar tarafindan Meryem'le özdeşleştirilmiştir. Hayvanlar arasına atıldığında çıplaklığının bir bulut tarafından gizlenmesi ise Tanrının Mısır'dan çıkışta İsrailoğullarına bir bulutla yaptığı ilahi müdahaleyi hatırlatır (Çıkış, 13: 21; 14: 19-20).

Sonuç olarak diyebiliriz ki; Tekla'nın çağları aşan bu yaygın ve uzun soluklu etkisinin ardında kadın görüntüsüyle eril bir gücü temsil etmesi yatmaktadır. $\mathrm{Bu}$ onun herkes tarafından sevilip yüceltilmesine ve hatırasının yaşatılmasına sebep olmuştur. 
${ }^{1}$ W.S. Lasor "Seleucia," The International Standard Bible Encyclopedia, Edit: Geoffrey W. Bromiley, Michigan: Wm. B. Eerdmans Publishing, 1995, IV/385; Siméon Vailhé, "Seleucia Trachea," The Catholic Encyclopedia, Vol. 13, New York: Robert Appleton Company, 1912. <http://www.newadvent.org/cathen/13689b.htm> 5-12-2011 tarihinde ulaş1ld.

${ }^{2}$ Murat Özyıldırım, 359 Yılı Seleucia Konsili Kararlarının Çözümlenmesi, ÏÜSBE, Latin Dili ve Edebiyatı Bilim Dalı, Yüksek Lisans Tezi, İstanbul 2006, s. 73. <http://www.belgeler.com/blg/18jn/359-yili-seleucia-konsili-kararlarinin-cozumlenmesi-analyse-of-thecouncil-decrees-of-seleucia-in-359> 4-12-2011 tarihinde ulaşıldı.

${ }^{3}$ Stephen J. Davis, The Cult of St. Thecla: A Tradition of Women's Piety in Late Antiquity, New York: Oxford University Press, 2008, s. V, VI.

${ }^{4}$ Rena Pederson, The Lost Apostle, San Francisco: John Wiley and Sons, 2006, s. 61.

${ }^{5}$ Davis, The Cult of St. Thecla, s. 4, 5.

${ }^{6}$ Pederson, The Lost Apostle, s. 62; Gillian Cloke, This Female Man of God: Women and Spiritual PowerIn the Patristic Age, AD 350-450, New York: Routledge, 2005, s. 101.

${ }^{7}$ Ross Shepard Kraemer (Ed.), Women's Religions in the Greko-Roman World, New York: Oxford University Press, 2004 s. 298.

${ }^{8}$ Katolik Kilisesi 1969 yılında bazı azizlerin adlarını resmi azizler listesinden çıkarma kararı almıştır. Tekla'nın adı da çıkarılanlar arasındadır. (Bkz. Leonie Hayne, "Thecla and Church Fathers," Vigiliae Christianae, Vol. 48, No. 3 (Sep., 1994), pp. 209-218/209) $<\mathrm{http}: / /$ www.jstor.org/pss/1584094> 29-12-2011 tarihinde ulaşıldı.

${ }^{9}$ Johann Peter Kirsch, "Sts. Thecla," The Catholic Encyclopedia, Vol. 14. New York: Robert Appleton Company, 1912.

$<$ http://www.newadvent.org/cathen/14564a.htm>. 8-12-2011 tarihinde ulaşıld1; Pederson, The Lost Apostle, s. 68; J. K. Elliott, The Apocryphal New Testament: A Collection of Apocryphal Christan Literature in an English Translation Based on M. R. James, New York: Oxford University Press, 2005, s. 353; Matthew Bunson, Margaret Bunson, Stephen Bunson, "Thecla" Our Sunday Visitor's Encyclopedia of Saints, Huntington, IN: Our Sunday Visitor Publishing, 2003, s. 784; Türkiye'de kutlanan Tekla Bayramı ile ilgili olarak bakınız: $<\mathrm{http}: / /$ www.samandagortodoks.com>.

${ }^{10} 11-15$. yüzyıllarda İspanyanın kuzeydoğusunda hüküm sürmüş krallık.

J. Gw. "Thecla" A Dictionary of Christian Biography, Literature, Sects and Doctrines, Edits: William Smith, Henry Wace, London: Elibron, 2005, IV/894.

${ }^{11}$ Davis, The Cult of St. Thecla, s. 85, 86.

${ }^{12}$ Pederson, The Lost Apostle, s. 68.

${ }^{13}$ Pederson, The Lost Apostle, s. 68.

${ }^{14}$ Elliott, The Apocryphal New Testament, s. 372.

${ }^{15}$ Dennis Ronald MacDonald, The Legend and The Apostle: The Battle for Paul in Story and Canon, Philadelphia: Westminster John Knox Press 1983, s. 92; Özyıldırım, 359 Yllı Seleucia Konsili, s. 38.

${ }^{16}$ W. M. Ramsay, ikinci yüzyılın ortalarına ait olduğu iddia edilen bu metnin tarihini birinci yüzyıla dayandırmakta israr eder. (C. C. Kroeger, "Women in the Early Church" Dictionary of the Later New Testament and Its Developments, Edits: Ralph P. Martin, Peter H. Davids, Leicester: InterVarsity Press, 1997, s. 1219); Metnin Eski Yunancasının yanı sıra Süryanice, Ermenice, Slavca ve Arapça versiyonları da vardır. (Bkz. David Edward Aune, The Westminster Dictionary of New Testament and Early Christian Literature and Rhetoric, Louisville: Westminster John Knox Press, 2003, s. 10; Elliot, The Apocryphal New Testament, s. 353.)

${ }^{17}$ Pavlus'un ilk görev yolculuğu M. 47'de Antakya'dan başlamış ve bir yıl sürmüştür. Buradan Barnabas ile birlikte deniz yoluyla Kıbrıs'a, Kıbrıs'tan da Perge'ye geçmişlerdir. Daha sonra Pisidya Antakya'sına (bugünkü Isparta şehrinin Yalvaç ilçesi yakınlarında) ve oradan kovulunca da Konya'ya gelmişlerdir. (Andreas J. Köstenberger, L. Scott Kellum, Charles Quarles, The Cradle, the Cross, and the Crown: An Introduction to the New Testament, Nashville:B\&H Publishing Group, 2009, s. 402; Ayrica bkz: Resullerin İşleri, 13:50-51)

18* Apokrif: Hıristiyanlıkta dinsel doğmaları belirlemede kaynak olarak kullanılmayan ve otantik olarak kabul edilmeyen metinlerdir. (Şinasi Gündüz, Din ve İnanç Sözlüğü, Ankara 1988, s. 38.) Bkz. Acts of Paul and Thecla, 1-22 (Bu çalışmada "Paul ve Tekla’nın İşleri” adlı yazmanın İngilizcesini kullandık. Bizim kullandığımız metin M. R. James'in çevirisine dayanan Elliot'un Apokrif İncillerle ilgili kitabının içerisinde yer alır. Verdiğimiz bölüm numaralarında bu eser esas alınmıştır. Bunun için bkz: "Acts of Paul and Thecla", Elliott, The Apocryphal New Testament, s.364-374) "Pavlus ve Tekla'nın İşleri” nin İngilizce tercümesi için şunlara da bakılabilir: Archbishop Wake, Forbidden Gospels and Epistles: Of the Original New Testament, Forgotten Books, 2008, 230-243; Aune, The Westminster Dictionary, s. 11.

${ }^{19}$ Bkz. Acts of Paul and Thecla, 22-43.

${ }^{20}$ Bkz. Acts of Paul and Thecla, 44-45.

${ }^{21}$ Carl Olson, "Celibacy and the Human Body: An Introduction," Celibacy and Religious Traditions, Edit: Carl Olson, New York: Oxford University Press, 2008, s. 9.

${ }^{22}$ Glenn Holland, "Celibacy in The Early Christian Church," Celibacy and Religious Traditions, s. 65.

${ }^{23}$ Olson, "Celibacy and the Human Body," Celibacy and Religious Traditions, s. 10.

${ }^{24}$ Holland, "Celibacy in The Early Christian Church," Celibacy and Religious Traditions, s. 65. 
${ }^{25}$ Olson, "Celibacy and the Human Body," Celibacy and Religious Traditions, s. 10.

${ }^{26}$ Deborah F. Sawyer, Women and Religion in the First Christian Centuries, New York and London: Routledge, 1996, s.78, 79; Olson "Celibacy and the Human Body", Celibacy and Religious Traditions, s. 10.

${ }^{27}$ Bkz. Çıkış 13: 1-2, 12.

${ }^{28}$ Bkz. Luka 2: 22-23, 27-28.

${ }^{29}$ On iki havarinin içinde evli olanlar da bekâr olanlar da vardır. Bkz. Markos 1: 29-31; I Korintliler 7: 7; 9: 6, 15; Peter'in eşi için bkz. I. Korintliler 9: 5.

${ }^{30}$ Olson, "Celibacy and the Human Body," Celibacy and Religious Traditions, s. 11.

${ }^{31}$ Bkz. Matta 19: 1-9; Markos 10: 1-12.

${ }^{32}$ Bkz. Matta 19: 12.

${ }^{33}$ Bkz. Matta 19: 10-11.

${ }^{34}$ Bkz. I. Korintlilere 7: 1-40; 6: 9-20; 5: 1-13.

${ }^{35}$ Bkz. Efeslilere 5: 21-33; 6: 1-4.

${ }^{36}$ Bazılarına göre Pavlus'un bu konudaki görüşleri karmaşık ve yanlış anlaşılmaya müsaittir. Çünkü onun Korintlilere yazdıkları sadece o şehri insanlarına yöneliktir ve geneli kapsamaz. Pavlus onların sorularına cevap vermiştir. Korint o dönemde ahlaksızlıklarıyla meşhur bir şehirdir. Ayrıca Pavlus bunları söylerken çağın sonuna gelindiğini düşünmektedir. Bu yüzden kendisi için bekârlı̆̆ı tercih etmiştir. (Bkz. Geoffrey Parrinder, Sexusal Morality in the World's Religions, Oxford: Oneworld Publications, 2003, s. 212.)

${ }^{37}$ Luke Timothy Johnson and Mark D. Jordan, “Christianity,” Sex, Marriage and Family in World Religions, Edits: Don S. Browning, M. Christian Green, John Witte Jr., New York: Columbia University Press, 2006, s. 94, 98.

${ }^{38}$ Helen Rhee, Early Christian Literature: Christ and Culture in the Second Third Centuries, London and New York: Routledge, 2005 , s. 125.

${ }^{39}$ Mary Gail Frawley-O'Dea, Perversion of Power:Sexual Abuse in the Catholic Church, Tennessee: Vanderbilt University Press, 2007, s. 88.

${ }^{40}$ Scott Fitzgerald Johnson, The Life and Miracles of Thekla: A Literary Study, Hellenic Studies Series XIII, Washington, DC: Center for Hellenic Studies, Trustees for Harvard University, 2006, s. 46.

${ }^{41}$ G1llian Clark "Women and Asceticism in Late Antiquity: The Refusal of Status and Gender," Asceticim, Edits: Vincent L. Wimbush and Richard Valantasis, New York: Oxford University Press, 1998, s. 35.

${ }^{42}$ Bkz. Matta 19: 17-23.

${ }^{43}$ Bkz. Matta 19: 29.

${ }^{44}$ Pederson, The Lost Apostle, s. 73.

${ }^{45}$ Clark "Women and Asceticism in Late Antiquity," s. 35.

${ }^{46}$ David R. Cartlidge, James Keith Elliott, Art and the Christian Apocrypha, New York: Routledge, 2001, s. 158.

${ }^{47}$ Jordan Aumann, Christian Spirtuality in The Catholic Tradition, San Francisco: Ignatius Press, 1985, s. 33.

${ }^{48}$ Jane Tibbetts Schulenburg, Forgetful of Their Sex: Female Sanctity and Society, ca. 500-1100, University of Chicago Press, Chicago1998, s. 155-157.

${ }^{49}$ Monika Pesthy "Thecla Among the Fathers of the Church," The Apocryphal Acts of Paul and Thecla Studies on Early Christian Apocrypha, Edit. Jan N. Bremmer, Kampen: Pharos Publishing, 1996, s. 166.

${ }^{50}$ Kilisede bu konudaki uygulamalarla ilgili olarak bakınız: O'Neill, James David. "Fast," The Catholic Encyclopedia. Vol. 5. New York: Robert Appleton Company, 1909. <http://www.newadvent.org/cathen/05789c.htm> adresinden 9 Ocak 2012 tarihinde ulaşıldı.

${ }^{51}$ Bkz. Matta 4: 2; Markos 1: 13; Luka 4: 1-2.

${ }^{52}$ Bkz. II. Korintliler 6: 5.

${ }^{53}$ Bkz. II. Korintliler 11: 27.

${ }^{54}$ Gillian Clark, Women and Asceticism in Late Antiquity: Pagan and Christian Lifestyles, New York: Oxford University Press, 1994, s. 78

${ }^{55}$ Aelred Baker "Fasting to the World," JSTOR, Vol.84, No:3 (September 1965), s. 291-294/292, 293.

${ }^{56}$ Ablan Butler, The Lives of the Father Martyrs and Other Principal Saints, London, 1821, s. 287, 288.

${ }^{57}$ Scott F. Johnson, The Life and Miracles of Thekla, s. 5-6.

${ }^{58}$ Scott F. Johnson, The Life and Miracles of Thekla, s. 148.

${ }^{59}$ Scott F. Johnson, The Life and Miracles of Thekla, s. 151. 
${ }^{60}$ Scott F. Johnson, The Life and Miracles of Thekla, s. 154.

${ }^{61}$ Scott F. Johnson, The Life and Miracles of Thekla, s. 158.

${ }^{62}$ Scott F. Johnson, The Life and Miracles of Thekla, s. 7.

${ }^{63}$ Monika Pesthy "Thecla Among the Fathers of the Church," The Apocryphal Acts of Paul and Thecla Studies s. 175.

${ }^{64}$ B. K. Kuiper, The Church in History, Michigan: Wm. B. Eerdmans Publishing, 1988, s. 7.

${ }^{65}$ Maurice Hassett, "Martyr," The Catholic Encyclopedia. Vol. 9. New York: Robert Appleton Company, 1910.

$<$ http://www.newadvent.org/cathen/09736b.htm>. 17-01-2012 tarihinde ulaş1ld1.

\section{Kaynakça}

Aumann, Jordan, Christian Spirtuality in The Catholic Tradition, San Francisco: Ignatius Press, 1985.

Aune, David Edward, The Westminster Dictionary of New Testament and Early Christian Literature and Rhetoric, Louisville: Westminster John Knox Press, 2003.

Baker, Aelred, "Fasting to the World," JSTOR, Vol.84, No:3 (September 1965), pp. 291-294.

Bunson, Matthew; Bunson, Margaret and Bunson, Stephen, “Thecla," Our Sunday Visitor's Encyclopedia of Saints, Huntington, IN: Our Sunday Visitor Publishing 2003.

Butler, Ablan, The Lives of the Father Martyrs and Other Principal Saints, London, 1821.

Cartlidge, David R., James Keith Elliott, Art and the Christian Apocrypha, New York: Routledge, 2001.

Clark, Gillian, Women and Asceticism in Late Antiquity: Pagan and Christian Lifestyles, New York: Oxford University Press, 1994.

Clark, G1llian, "Women and Asceticism in Late Antiquity: The Refusal of Status and Gender," Asceticim, Edits: Vincent L. Wimbush and Richard Valantasis, New York: Oxford University Press, 1998.

Cloke, Gillian, This Female Man of God: Women and Spiritual Powerin the Patristic Age, AD 350-450, New York: Routledge, 2005.

Davis, Stephen J., The Cult of St. Thecla: A Tradition of Women's Piety in Late Antiquity, New York: Oxford University Press, 2008.

Elliott, J. K., The Apocryphal New Testament: A Collection of Apocryphal Christan Literature in an English Translation Based on M. R. James, New York: Oxford University Press, 2005.

Frawley-O'Dea, Mary Gail, Perversion of Power:Sexual Abuse in the Catholic Church, Tennessee: Vanderbilt University Press, 2007.

Gündüz, Şinasi, Din ve İnanç Sözlü̆̆̈̈, Ankara 1988.

Gw., J., "Thecla," A Dictionary of Christian Biography, Literature, Sects and Doctrines, Vol: IV, Edits: William Smith, Henry Wace, London: Elibron 2005.

Holland, Glenn, "Celibacy in The Early Christian Church," Celibacy and Religious Traditions, Edit: Carl Olson, New York: Oxford University Press, 2008.

Johnson, Luke Timothy and Jordan, Mark D., "Christianity," Sex, Marriage and Family in World Religions, Edits: Don S. Browning, M. Christian Gren and, John Witte Jr., New York: Columbia University Press, 2006.

Johnson, Scott Fitzgerald, The Life and Miracles of Thekla: A Literary Study, Hellenic Studies Series XIII, Washington, DC: Center for Hellenic Studies, Trustees for Harvard University, 2006.

Köstenberger, Andreas J., Kellum, L. Scott and Quarles, Charles, The Cradle, the Cross, and the Crown: An Introduction to the New Testament, Nashville: B\&H Publishing Group, 2009.

Kraemer, Ross Shepard, (Ed.), Women's Religions in the Greko-Roman World, New York: Oxford University Press, 2004.

Kroeger, C. C., "Women in the Early Church," Dictionary of the Later New Testament and Its Developments, Edits: Ralph P. Martin, Peter H. Davids, Leicester: InterVarsity Press, 1997.

Kuiper, B. K., The Church in History, Michigan: Wm. B. Eerdmans Publishing, 1988. 
MacDonald, Dennis Ronald, The Legend and The Apostle: The Battle for Paul in Story and Canon, Philadelphia: Westminster John Knox Press, 1983.

Lasor, W.S., "Seleucia," The International Standard Bible Encyclopedia, Vol: IV Edit: Geoffrey W. Bromiley, Michigan: Wm. B. Eerdmans Publishing 1995.

Olson, Carl, "Celibacy and the Human Body: An Introduction," Celibacy and Religious Traditions, Edit: Carl Olson, New York: Oxford University Press, 2008.

Parrinder, Geoffrey, Sexusal Morality in the World's Religions, Oxford: Oneworld Publications, 2003.

Pederson, Rena. The Lost Apostle, San Francisco: John Wiley and Sons, 2006.

Pesthy, Monika, "Thecla Among the Fathers of the Church," The Apocryphal Acts of Paul and Thecla Studies on Early Christian Apocrypha, Edit. Jan N. Bremmer, Kampen: Pharos Publishing, 1996.

Rhee, Helen, Early Christian Literature: Christ and Culture in the Second Third Centuries, London and New York: Routledge 2005, s. 125.

Sawyer, Deborah F., Women and Religion in the First Christian Centuries, New York and London: Routledge, 1996.

Schulenburg, Jane Tibbetts, Forgetful of Their Sex: Female Sanctity and Society, ca. 500-1100, Chicago: University of Chicago Press, 1998.

Wake, Archbishop, Forbidden Gospels and Epistles: Of the Original New Testament, Forgotten Books, 2008.

\section{Web Kaynakları}

Özyıldırım, Murat, 359 Yılı Seleucia Konsili Kararlarının Çözümlenmesi, İÜSBE, Latin Dili ve Edebiyatı Bilim Dalı, Yüksek Lisans Tezi, İstanbul 2006, s. 73. <http://www.belgeler.com/blg/18jn/359-yili-seleucia-konsili-kararlarinin-cozumlenmesianalyse-of-the-council-decrees-of-seleucia-in-359> 4-12-2011 tarihinde ulaşıldı.

Hassett, Maurice, "Martyr." The Catholic Encyclopedia. Vol. 9. New York: Robert Appleton Company, 1910. $<$ http://www.newadvent.org/cathen/09736b.htm>. 17-01-2012 tarihinde ulaşıldı.

Kirsch, Johann Peter, "Sts. Thecla." The Catholic Encyclopedia, Vol. 14. New York: Robert Appleton Company, 1912. $<\mathrm{http}$ //www.newadvent.org/cathen/14564a.htm>. 8-12-2011 tarihinde ulaşıldı.

Hayne, Leonie, “Thecla and Church Fathers,” Vigiliae Christianae, Vol. 48, No. 3 (Sep., 1994), pp. 209-218/209) $<\mathrm{http}$ ://www.jstor.org/pss/1584094> 29-12-2011 tarihinde ulaş1ld.

O'Neill, James David, "Fast." The Catholic Encyclopedia, " Vol. 5. New York: Robert Appleton Company, 1909. $<$ http://www.newadvent.org/cathen/05789c.htm> adresinden 9 Ocak 2012 tarihinde ulaş1ld.

Vailhé, Siméon, "Seleucia Trachea." The Catholic Encyclopedia," Vol. 13, New York: Robert Appleton Company, 1912. $<\mathrm{http}: / /$ www.newadvent.org/cathen/13689b.htm> 5-12-2011 tarihinde ulaş1ld.

Tekla Bayramı için: <http://www.samandagortodoks.com>. 